\title{
Intellectual Property in Mexican Small Business: An Empirical Research
}

\author{
Gonzalo Maldonado-Guzman ${ }^{1}$, Sandra Yesenia Pinzón-Castro ${ }^{1}$, \& José Trinidad Marín-Aguilar ${ }^{1}$ \\ ${ }^{1}$ Economic and Administrative Science Centre, Autonomous University of Aguascalientes, Mexico \\ Correspondence: Gonzalo Maldonado-Guzman, Economic and Administrative Science Centre, Autonomous \\ University of Aguascalientes, Avenida Uni versidad No. 940, Ciudad Uni versitaria, C.P. 20131, Aguascalientes, \\ Mexico.
}

\author{
Received: March 20,2017 Accepted: April 12,2017 Online Published: April 18, 2017 \\ doi:10.5539/ibr.v10n5p107 URL: https://doi.org/10.5539/ibr.v10n5p107
}

\begin{abstract}
Intellectual property is an important topic that has been usually analyzed in big enterprises from developed countries but it has been overlooked a lot in its analysis and discussion within the context of small and medium-sized enterprises (SMEs) from both developed and economically emergent countries even when they represent more than $98 \%$ of all enterprises, provide jobs to more than $50 \%$ of the labor force and produce more than $50 \%$ of the Gross Domestic Product (GDP) of any country. Thus, the main goal of this empirical research is the measurement of intellectual property in small and medium-sized enterprises through three factors: patents, brand registration and image investment by considering a sample of 125 enterprises established in Aguascalientes State (Mexico). The results obtained show that patents, brand registration and image investment seem to be good measurements of intellectual property in small and medium-sized enterprises.
\end{abstract}

Keywords: intellectual property, patents, brand registration, small business

\section{Introduction}

Some decades ago, Arrow (1962) had already considered that markets were a fundamental source that provides an optimal level of innovation in services for the economy of any country. The existence of traditional markets with no level of innovation is an important aspect that gets an increasing interest among researchers focused in the development and implementation of market policies because innovation is usually acknowledged as an essential element that can provide higher productivity and growth in nations (Jensen \& Webster, 2006). As a result, government authorities have implemented a series of public policies or rights of appropriation such as the intellectual property rights which have soften the effects of the low level of innovation of markets as they provide legal resources to enterprises in an effort to prevent imitations from their competitors.

In this regard, intellectual property rights are considered by several small and medium-size enterprises (SMEs) as too costly. This can create disadvantages to SMEs when compared with big enterprises in the development of skills for the use of intellectual property rights which produce a low level of innovation in SMEs (Cordes et al., 1999; WIPO, 2003; Macdonald, 2004; Jensen \& Webster, 2006). The investigation of Arundel and Kabla (1998) provides empirical evidence by showing that SMEs from Europa have a low tendency to patent their innovations in comparison to big enterprises. In a more recent study, Jensen and Webster (2006) proved that SMEs from Australia have lower patent registrations, trademarks and industrial designs than big enterprises.

On the other hand, the potential of investigation from SMEs in the different innovation activities is an essential policy that government authorities must consider as this indicates that it is an important indicator of a basic element to promote creativity in the economy (Jensen \& Webster, 2006). Nowadays, the potential contribution that SMEs have in an increasingly globalized and competitive market is very limited because of several barriers that stop or inhibit the use of the system of intellectual property. An example of this is the restricted access to finance the investment in aspects of intellectual property or the acquisition of patents, the registration of brands and the factors of copyright, which implies the necessary intervention of government authorities (Jensen \& Webster, 2006).

Similarly, the constant increase in opportunities provided by the international market and the globalization of economy and markets force SMEs to implement the necessary actions to protect their intellectual property since 
patents, the registration of brands, copyright and industrial classified information are essential factor that SMEs must protect to preserve the use of their products, processes or services (Lloyd, 1995). However, SMEs can easily fail in their attempt to protect their intellectual property for different reasons such as the changes in the interests of clients, the government regulations and the increase of competition, which can make that both their products and services become duplicated by other companies, especially by big enterprises in countries that have a low level of industrial protection (Lloyd, 1995).

Thus, India, Thailand and Taiwan are the Asian countries that constantly break the protection laws of intellectual property, even when the same problems take place in South Korea, Indonesia and the Philippines, which has created a lot of international pressure on these Asian countries so they change their laws. This has forced different companies located in Asia to move to Western Europe and Latin America where the political and economic laws are more permissible to the violation of intellectual property rights (Awanohara, 1992). However, places like Hong Kong, Taiwan and China continue with the same laws as there is a strong international opposition, mostly from the United States of America, to force these countries to adopt more strict measures for the protection of intellectual property rights from both small enterprises and big corporations (Blass, 1992; Lloyd, 1995).

Consequently, the few published empirical investigations in the current literature that analyzes intellectual property in SMEs have focused in developed countries (for example Arundel \& Kabla, 1998; Kitching \& Blackburn, 1998; Cohen et al., 2000; Cordes et al., 1999; WIPO, 2003; Blind et al., 2003; Macdonald, 2004; Jensen \& Webster, 2006; Birk, 2006; Päällysaho \& Kuusisto, 2011). However, there was not a single empirical research of SMEs in emerging countries; this creates the necessity to deepen in the analysis and discussion of intellectual property of SMEs in emerging or developing countries (Lloyd, 1995; Päällysaho \& Kuusisto, 2011).

Within this set of ideas, the first contribution of this empirical research is the analysis of intellectual property of SMEs in an emerging country as it is the case of Mexico as well as the contribution to the methodology used, a model of structural equations to analyze the theoretical model of intellectual property as a whole. The rest of the work has been organized in the following way: the second section examines the theoretical framework, the previously published empirical investigations and the investigation hypotheses are established; the third section shows the methodology, the sample and the variables used; the fourth section analyzes the results obtained and, finally, the fifth section shows the main conclusions and the research discussion.

\section{Method}

Significant differences can be observed in the literature between big enterprises and SMEs regarding the use of intellectual property systems which can be created by multiple factors. Some of the most important ones can be the differences at the level of innovation since big enterprises have a higher number of patents than SMEs, because they have the necessary and adequate resources to develop a higher level of innovation (Jensen \& Webster, 2006). However, both big enterprises and SMEs can develop similar levels of innovation; the problem is that SMEs have a lower capacity to obtain the necessary financing to register their patents.

In this regard, the relation between intellectual property and innovation has been analyzed and discussed slightly, in the context of SMEs in the literature of economy and business management. At the beginning of the third decade of the $19^{\text {th }}$ century, Schumpeter (1934) had already considered that big enterprises were more innovative than SMEs, because they have a higher financial capacity to reinvest in innovation activities of high risk, which can provide them higher competitive advantages both in investigation and de velopment activities as well as in innovation of processes. Considering that big enterprises usually have a higher production of goods and, consequently, higher profit than SMEs, it becomes understandable to consider that they can have a higher capacity to absorb costs that create innovation activities (Jensen \& Webster, 2006).

Nonetheless, the literature also provides empirical evidence against this approach since SMEs can have different competitive advantages in the inno vation activities in comparison to big enterprises, because they generally have more precise information about the requirements and needs of clients and consumers and, mostly, about the benefits and expenses in the development of innovation activities (Arrow, 1983), which can create a better protection of intellectual property from innovation activities (Acs et al., 1997). Moreover, SMEs can also have a higher inertia and a higher capacity to recognize market niches run by big enterprises (Rogers, 2004; Jensen \& Webster, 2006).

On the other hand, there are few published papers in the literature that analyze the use of intellectual properties of SMEs. Among the limited number of investigations that consider these two constructs are the ones of Lloyd (1995), Kitching and Blackburn (1998); Iversen (2002), CHI Research (2003), WIPO (2003), Hanel (2004), Jensen and Webster (2006); Bérard and Delerue (2010) as well as Päällysaho and Kuusisto (2011). However, 
these papers analyze the relation of these two constructs by simply comparing the number of intellectual property rights that SMEs have, and as a result this type of analysis is very limited because only the intensity in the use of intellectual property, is considered instead of the absolute value of the use from SMEs, which would be more appropriate and interesting.

As a matter of fact, intellectual property rights such as patents, brand registration, copyright and industrial secrets are usually irrelevant for a considerable number of SMEs (Blind et al., 2003), since the formal intellectual protection of their innovation activities is generally not considered as a priority within their business strategies. As a result, many SMEs that evaluate intellectual property rights adequately have probably never implemented some type of formal mechanism to protect their intellectual property (Tang \& Molas-Gallart, 2004). Accordingly, a recent study about intellectual property in SMEs shows that only 23\% of this type of enterprises, had made a process for the protection of their intellectual property in the last five years, and only $8 \%$ had obtained a patent (Birk, 2006).

Similarly, the literature considers that SMEs do not have an effective protection system of their patents that avoids the imitation of their products or services from their main competitors, or they simply consider that the protection of their patents is irrelevant since the cycles of technology development are shorter every time (Blind et al., 2003). Consequently, the high costs produced by the protection of intellectual property is considered as one of the most important barriers, that halt or inhibit its implementation along with the difficulties faced by SMEs in legal processes to exert the law to intellectual property right (Päällysaho \& Kuusisto, 2011).

Simultaneously, there are different SMEs that are constantly protecting their intellectual property rights, especially SMEs that have an industrial activity that is based in intensive knowledge, which is regularly producing several high knowledge and basic knowledge products or services that need a patent to be legally protected (European Patent Office, 2007). This situation can be seen frequently in most SMEs that work within a system of high biotechnological development and in the pharmaceutical industry. They need patents to continue working; that is why the protection of their intellectual property rights is essential (Macdonald, 2004; Moulin \& Thue-Lie, 2005).

Despite this empirical evidence, a considerable number of SMEs prefer to carry out informal protection practices of intellectual property, before adopting legal actions (Kitching \& Blackburn, 2003). However, the protection of intellectual property rights represents only a small part of the management and protection of practices, within intellectual property implemented by SMEs since there is a wide variety of activities to protect intellectual property, that do not compete against each other but imply a relation among them (Kuuasisto et al., 2005). These intellectual property practices are relatively simple and easy to control for SMEs, their use is economical and they are part of the regular working activities inside organizations (Päällysaho \& Kuusisto, 2011).

Likewise, informal practices of intellectual property protection are too heterogeneous among themselves, and they are usually the result of the limited knowledge that SMEs have about intellectual property, and the interaction that it has with the community in general where it develops (Päallysaho \& Kuusisto, 2008). Thus, informal practices of intellectual property protection provide very valuable information for researches (Kitching \& Blackburn, 1998; Miles et al., 2000; Blind et al., 2003). Moreover, the different informal methods of intellectual property protection attempt to defend SMEs from internal risks, that they may face when firing employees that have valuable knowledge for the organization (Päällysaho \& Kuusisto, 2011).

Regarding the informal methods of intellectual property protection, the most common ones in the literature are patents, brand registration and copyright (Lloyd, 1995; WIPO, 2003; Jensen \& Webster, 2006). For example, in the case of patents in the United States of America, their registration implies the exclusive use or sale of inventions for a period of 17 years and such patents can be obtained for new processes, machinery, manufacturing articles, the creation of new or improved materials and special patents called plant breeder's rights which can be given to plants and ornamental designs (Lykes, 1994).

As a result of this, the appointment of patents also includes industrial designs and the designs of finished products. Nonetheless, in the case of new designs of furniture such as a lamp or a chair, the patent is the most appropriate method of intellectual property protection rather than copyright (Augustine, 1993). As a result, inventions are generally more prone to the acquisition of patents to protect both the professional activities of staff and the organization itself without decreasing the invention practices (Lloyd, 1995). Furthermore, patents can describe inventions with greater detail and the skills needed in a specific field where the invention is used (Grolier, 1995).

Additionally, patents produce important changes in the assurance of financing capital as there are several SMEs that are intensive regarding their knowledge and depend on the patent of their products or services for their survival and development because their portfolio of patents is usually the only economic capital that they have 
(Levin et al., 1987). Therefore, considering the information presented above, it is possible at this point to state the first hypothesis.

\section{H1: The higher the use of patents, the higher the intellectual property of SMEs.}

Regarding the registration of brands, they can take the name of a product or service and an incorporation certificate is usually given so the SME or organization, can use automatically the name to label their products or services in a legal way and, consequently, avoid its use by other enterprises (Lloyd, 1995). However, the registration of a brand can become invalid if the SME uses a brand, that does not belong to it and uses it to label similar products or services since this type of registration can usually include commercial names, the names of services, slogans of enterprises and symbols (U.S. Department of Commerce, 1992).

In a similar way to patents, it is advisable to visit the patents deposit from government institutions in their country before SMEs, do the process of brand registration to determine first if the brand intended to be registered exists, even when several SMEs consider that the costs of carrying out this process are high (Steinberger, 1990). Likewise, SMEs need to obtain precise and verified information about brand registration, current costs, different forms of implementation and other additional requirements depending on the country where the registration takes place (U.S. Department of Commerce, 1992). As a result of this, and considering the information presented above, the second research hypothesis can be stated.

H2: The higher the use of brands, the higher the intellectual property of SMEs.

Accordingly, intellectual property protection has different additional objectives to the traditional reasons of making a profit from innovation activities (Harabi, 1995; Cohen et al., 2000), such as the creation of an image and reputation in business from which SMEs can obtain a social and business status in the ability to develop new products or services (Pällysaho \& Kuusisto, 2011). Thus, it important the investment on marketing activities carried out by enterprises for the improvement of their image, and the image of their products and services which can produce the adoption of intellectual property protection activities (Jensen \& Webster, 2006; Pälllysaho \& Kuusisto, 2011). Therefore, considering the information presented above, the third hypothesis can be stated.

H3: The higher the image investment, the higher the intellectual property of SMEs.

\subsection{Sampling Procedures}

In order to answer the research hypotheses established in the theoretical model of intellectual property, an empirical research was carried out in manufacturing SMEs from Aguascalientes State (Mexico), by using as a reference framework the directory of the Sistema de Información Empresarial de México (Business Information System of Mexico) for Aguascalientes State, which had 130 registered enterprises with 20 to 250 employees on July 30, 2016. Because the population of SMEs was too small, it was decided to apply a census among all SMEs considered. Moreover, the questionnaire was designed to be answered by managers of SMEs and implemented as a personal interview to the 130 selected enterprises. Only 125 questionnaires were answered and returned; five were eliminated because they were completed. This represents a reply rate of $96 \%$. Table 1 presents the most important aspects of the research.

Table 1. Research design

\begin{tabular}{ll}
\hline \multicolumn{1}{c}{ Features } & \multicolumn{1}{c}{ Survey } \\
\hline Universe & 130 small and medium-sized enterprises \\
Geographic Area & Aguascalientes State (México) \\
Sample Unit & SMEs 20 to 250 Employees \\
Collection Method of Data & Personal Survey at the Managers \\
Sampling Rate & Simple Random \\
Sample Size & 125 SMEs \\
Margin of Sample Error & $\pm 1 \%$ error, to a confidence level of $99 \%(\mathrm{p}=\mathrm{q}=0.5)$ \\
Date of Fieldwork & September - December 2016 \\
\hline 2.2 Measures and Covariates &
\end{tabular}

For the measurement of the variables of intellectual property, managers and/or owners of SMEs were asked to indicate whether their enterprises had carried out any type of inventions, registration of distinctive signs or investments in the improvement of image $(1=$ Yes, $0=$ No). For the measurement of the degree of importance of intellectual property, managers and/or owners were asked to evaluate the inventions, registration of distinctive signs or investments in the improvement of image with a Likert-type scale of five points (where $1=$ Not important and 5 $=$ very important as their limits). Additionally, three adapted factors from WIPO (2003) and Jensen and Webster (2006) were considered: 1) Patents measured by means of a four-item scale; 2) Registration of Brands measured by means of a four-item scale; and 3) Image Investment measured by means of a nine-item scale. All the items of the 


\section{Results}

The theoretical model of intellectual property was analyzed in order to prove the hypotheses established in the theoretical frame by using the structural equations model with the help of the software EQS 6.1 (Bentler, 2005; Brown, 2006; Byrne, 2006). Similarly, the nomological validity of the theoretical model was analyzed through the square Chi test. It was mostly based on the comparison of the results obtained from the original model and the measurement model; that provided non-significant results which provide an explanation of the relations observed between the constructs (Anderson \& Gerbing, 1988; Hatcher, 1994). The results obtained can be seen in a more detailed way in Table 4.

Table 4. Results of the structural equation model of the theoretical model

\begin{tabular}{|c|c|c|c|c|c|}
\hline Hypothesis & \multicolumn{3}{|c|}{ Structural Relationship } & \multirow{2}{*}{$\begin{array}{c}\begin{array}{c}\text { Standardized } \\
\text { Coefficient }\end{array} \\
0.409 * * *\end{array}$} & \multirow{2}{*}{$\begin{array}{c}\begin{array}{c}\text { Robust } \\
\text { t-Value }\end{array} \\
5.452\end{array}$} \\
\hline $\begin{array}{l}\text { H1: Higher use of patents, higher } \\
\text { intellectual property. }\end{array}$ & Patents & $\rightarrow$ & Intellectual $\mathrm{P}$. & & \\
\hline $\begin{array}{l}\text { H2: Higher use of brands, higher } \\
\text { intellectual property. }\end{array}$ & Trade Marks & $\rightarrow$ & Intellectual P. & $0.549 * * *$ & 4.849 \\
\hline $\begin{array}{l}\text { H3: Higher image investment, higher } \\
\text { intellectual property. }\end{array}$ & Image Inv. & $\rightarrow$ & Intelelctual P. & $0.479 * * *$ & 16.547 \\
\hline
\end{tabular}

The results of implementing the structural equations model are presented in Table 4 and they indicate, regarding hypothesis $\mathbf{H 1}(\beta=0.409, \mathrm{p}<0.01)$, that the use of patents really have a significant positive effect in intellectual property in Mexican manufacturing SMEs. Regarding hypothesis H2, the results obtained $(\beta=0.549, p<0.01)$ indicate that the use of brands also has a significant positive effect in intellectual property of SMEs. Finally, regarding hypothesis $\mathbf{H 3}$, the results obtained $(\beta=0.479, \mathrm{p}<0.01)$ indicate that the improvement of image also has a significant positive effect in intellectual property in Mexican manufacturing SMEs. Therefore, it can be confirmed that intellectual property in manufacturing SMEs can be measured without problems by using three factors or dimensions: patents, brands and image investment.

\section{Discussion}

According to the results obtained in this empirical research, it is possible to conclude in two fundamental aspects. Firstly, the registration of patents, brands and image investment have positive significant effects in intellectual property in manufacturing SMEs. Secondly, the intellectual property of this kind of enterprises can be measured through the registration of patents, the registration of brands and image investment. Consequently, if manufacturing SMEs intend to protect legally their intellectual property rights, they will have to create an environment that promotes and stimulates all activities related to improve significantly patents and brands and also increase prominently the resources to develop the image of both their products and the organization itself.

On the other hand, the registration of patents will allow manufacturing SMEs to have legal protection of their invention as well as the possibility of marketing such inventions; otherwise this can create serious problems to the organization because its patents can be used illegally by other enterprises. Thus, the legal registration of patents will have to be incorporated to the business strategy of manufacturing SMEs and all the functional areas or departments of the enterprise will need to work in coordination together so the patents they are using (even the ones they are developing) have legal protection through intellectual property.

Similarly, the registration of different brands from manufacturing SMEs will be fundamental for the growth and development of the organization because enterprises will improve significantly through their brands regarding their market position as well as the current and future ranking of products in the minds of their clients and consumers. Furthermore, the legal protection of intellectual property of brands from manufacturing SMEs can also facilitate the adoption and implementation of innovation activities. From the total of the economic benefits that can be obtained from the commercial exploitation of the organization's brands, a part of them can used to the development of new products or the improvement of existing products.

Moreover, the image investment also plays an essential role in the legal protection of intellectual property of manufacturing SMEs because it is precisely through this how organizations can increase not only their market position but also the ranking of the brand of their products and the very image of the enterprise. Additionally, the image investment allows clients and consumers to have acknowledgement and loyalty to the products offered by stores above the ones of their main competitors. This implies that current and future clients/consumers will prefer to obtain products from manufacturing SMEs which will create a significant increase in sales and income as well as economic return of enterprises. 
Likewise, this empirical research has different limitations that are important to mention at this point. The first limitation is the use of the scale to measure intellectual property since it only considers three factors or dimensions. Further investigations will need to incorporate different factors to verify the results obtained. A second limitation is the one related to the information obtained since only a part of the patent registration, brands and image investment was considered to be measured with qualitative variables. Further investigations will need to use quantitative variables to verify if similar results are obtained.

A third limitation is the measurement of the variables used since only three items were considered to measure the registration of patents, the registration brands and nine items to measure image investment. Further investigations will need to incorporate or add some other items to verify the results obtained. A fourth limitation is that the questionnaire was applied only to managers and/or owners of manufacturing SMEs of Aguascalientes State (Mexico) so the results may be different if another population is used. Further investigations will need to apply the questionnaire to both clients and suppliers of enterprises to verify the results obtained.

A fifth limitation is that the only manufacturing enterprises considered for the research had from 20 to 250 employees. As a result of this, further investigations will need to consider the enterprises that have less than 20 employees which represent more than half of the total of the enterprises established in Aguascalientes to verify the results obtained. A final limitation is that most of the enterprises interviewed considered that the information requested was confidential so the information provided may not necessarily reflect the real situation of enterprises.

Finally, it is important to go beyond the results obtained and discuss more deeply the following: what effects could have manufacturing SMEs if quantitative scales were used to measure intellectual property? What results would be obtained if a more sophisticated model were used in manufacturing SMEs for the measurement of intellectual property? What results would be obtained if other factors or dimensions were used for the intellectual property of manufacturing SMEs? These and other questions that may arise could be answered in future investigations.

\section{References}

Acs, Z. J., Mork, R., Shaver, J. M., \& Yeung, B. (1997). The internationalization of small and medium-sized enterprises: a policy perspective. Small Business Economics, 9(1), 7-20. https://doi.org/10.1023/A:1007991428526

Anderson, J., \& Gerbing, D. (1988). Structural equation modeling in practice: a review and recommended two-step approach. Psychological Bulletin, 13, 411-423. https://doi.org/10.1037/0033-2909.103.3.411

Arrow, K. J. (1962). Economic welfare and the allocation of resources for invention. In K.J Arrow (Ed.), The rate and direction of inventive activity: Economic and social factors. Princeton, NJ: Princeton University Press. https://doi.org/10.1515/9781400879762-024

Arrow, K. J. (1983). Innovation in large and small firms. In J., Ronen (Ed.), Entrepreneurship. Massachusetts: Lexington Books.

Arundel, A., \& Kabla, I. (1998). What percentage of innovations are patented? Empirical estimates for European firms. Research Policy, 27, 127-141. https://doi.org/10.1016/S0048-7333(98)00033-X

Augustine, M. J. (1993). Intellectual property rights. Interiors, 158, 28-30.

Awanohara, S. (1992). Roll of dishonor: Asian countries head list of US targets. Far Eastern Economic Review, 155, 46-47.

Bagozzi, R. P., \& Yi, Y. (1988). On the evaluation of structural equation models. Journal of the Academy of Marketing Science, 16(1), 74-94. https://doi.org/10.1007/BF02723327

Bentler, P. M. (1990). Comparative fit indexes in structural models. Psychological Bulletin, 107(2), 238-246. https://doi.org/10.1037/0033-2909.107.2.238

Bentler, P. M. (2005). EQS 6 structural equations program manual. Encino, CA: Multivariate Software.

Bentler, P. M., \& Bonnet, D. (1980). Significance tests and goodness of fit in analysis of covariance structures. Psychological Bulletin, 88(3), 588-606. https://doi.org/10.1037/0033-2909.88.3.588

Bérard, C., \& Delerue, H. (2010). A cross-cultural analysis of intellectual asset protection in SMEs: The effect of environmental scanning. Journal of Small Business and Enterprise Development, 17(2), 167-183. https://doi.org/10.1108/14626001011041193

Birk, F. (2006). The use of intellectual property rights among Nordic service companies. Oslo: Nordic Innovation Center. 
Blass, A. (1992). Learning the soft way. Far Eastern Economic Review, 155, 54-56.

Blind, K., Edler, J., Schmoch, U., Anderson, B., Howells, J., Miles, I., ...Herstatt, C. (2003). Patents in the service industries. Final Report, FhG-ISI, Karlsruhe.

Brown, T. (2006). Confirmatory factor analysis for applied research. New York, NY: The Guilford Press.

Byrne, B. (2006). Structural equation modeling with EQS, basic concepts, applications, and programming. 2th Edition, London: LEA Publishers.

Byrne, B. M. (1989). A primer of LISREL: Basic applications and programming for confirmatory factor analysis analytic models. New York, NY: Springer. https://doi.org/10.1007/978-1-4613-8885-2

Chau, P. (1997). Reexamining a model for evaluating information center success using a structural equation modeling approach. Decision Sciences, 28(2), 309-334. https://doi.org/10.1111/j.1540-5915.1997.tb01313.x

CHI Research. (2003). Small serial innovators: The small firm's contribution to technical change. New Jersey, NJ: Haddon Heights.

Chou, C. P., Bentler, P. M., \& Satorra, A. (1991). Scaled test statistics and robust standard errors for nonnormal data in covariance structure analysis. British Journal of Mathematical and Statistical Psychology, 44, 347-357. https://doi.org/10.1111/j.2044-8317.1991.tb00966.x

Cohen, W. M., Nelson, R. R., \& Walsh, J. P. (2000). Protecting their intellectual Assets: Appropriability conditions and why U.S. manufacturing firms patent (or not). NBER Working Paper No. W7552.

Cordes, J., Hertzfeld, H., \& Vonortas, N. (1999). A survey of high technology firms. Office of Chief Counsel for Advocacy, United States Small Business Administration.

European Patent Office. (2007). EPO Scenarios for the future: How might IP regimes evolve by 2025? What global legitimacy might such regime have? Munich: European Patent Office.

Fornell, C., \& Larcker, D. (1981). Evaluating structural equation models with unobservable variables and measurement error. Journal of Marketing Research, 18(1), 39-50. https://doi.org/10.2307/3151312

Garcia, P. L. D., Martinez, S. M. C., \& Maldonado, G. G. et al. (2009). Innovación y cultura empresarial de las MiPymes de Aguascalientes. México: Editorial UAA.

Grolier Multimedia Encyclopedia. (1995). Danbury CT. New York, NY: Grolier Electronic Publishing Inc.

Hair, J. F., Anderson, R. E., Tatham, R. L., \& Black, W. C. (1995). Multivariate data analysis with readings. New York, NY: Prentice-Hall.

Hanel, P. (2004). Current intellectual protection practices by manufacturing firms in Canada. Mimeo, Sherbrooke: University of Sherbrooke.

Harabi, N. (1995). Appropriability of technical innovations: An empirical analysis. Research Policy, 24(6), 981-992. https://doi.org/10.1016/0048-7333(94)00812-4

Hatcher, L. (1994). A step by step approach to using the SAS system for factor analysis and structural equation modeling. Cary, NC: SAS Institute Inc.

Heck, R. H. (1998). Factor analysis: Exploratory and confirmatory approaches. In G.A. Marcoulides (Ed.), Modern methods for business research. Mahwah, NJ: Lawrence Erlbaum Associates.

Hu, L. T., Bentler, P. M., \& Kano, Y. (1992). Can test statistics in covariance structure analysis be trusted? Psychological Bulletin, 112(2), 351-362. https://doi.org/10.1037/0033-2909.112.2.351

Hughes, A. (2001). Innovation and business performance: Small entrepreneurial firms in the UK and the US. New Economy, 8(3), 157-163. https://doi.org/10.1111/1468-0041.00208

Iversen, E. (2002). Norwegian SMEs and the IPR-System: Exploration and analysis. Mimeo, Oslo: Centre for Innovation Research.

Jensen, P. H., \& Webster, E. (2006). Firm size and the use of the intellectual property rights. Economic Record, 82(256), 44-55. https://doi.org/10.1111/j.1475-4932.2006.00292.x

Jöreskog, K. G., \& Sörbom, D. (1986). LISREL VI: Analysis of linear structural relationships by maximum likelihood, instrumental variables and square methods. Moorsville, IN: Scientific Software.

Kitching, J., \& Blackburn, R. (1998). Intellectual property management in the small and medium enterprises (SME). Journal of Small Business \& Enterprise Development, 5(4), 327-335. 


\section{https://doi.org/10.1108/EUM0000000006797}

Kitching, J., \& Blackburn, R. (2003). Innovation, intellectual property and informality. In R., Blackburn (Ed.), Intellectual property and innovation management in small firms. London: Routledge. https://doi.org/10.4324/9780203466278.ch2

Kuusisto, J., Päällysaho, S., \& Kulmala, R. (2005). Informal ways to protect intellectual property in small and medium-size business. Final Report, ProACT Project.

Levin, R. C., Klevorick, A. K., Nelson, R. C., \& Winter, S. G. (1987). Appropriating the returns from industrial research and development. Brooking Papers on Economic Activity, 3, 783-831. https://doi.org/10.2307/2534454

Lloyd, W. F. (1995). Intellectual property rights \& associated challenges for small business. Journal of Business \& Entrepreneurship, 7(2), 93-102.

Lykes, C. (1994). Intellectual property law for small business. Small Business Development Center Perspectives, 2, 9-11.

Macdonald, S. (2004). When means become ends: considering the impact of patent strategy on innovation. Information Economic and Policy, 16, 135-158. https://doi.org/10.1016/j.infoecopol.2003.09.008

Miles, I., Anderson, B., Boden, M., \& Howells, J. (2000). Service production and intellectual property. International Journal of Technology Management, 20(1/2), 95-115. https://doi.org/10.1504/IJTM.2000.002860

Moulin, A., \& Thue-Lie, H. (2005). Intellectual property rights and Nordic SMEs: A study of IPR practice in the IT and biotech sectors. Oslo: Leogriff AS.

Nunnally, J. C., \& Bernstein, I. H. (1994). Psychometric theory. $3^{a}$ Ed. New York, McGraw-Hill.

Päällysaho, S., \& Kuusisto, J. (2008). Intellectual property (IP) protection as a key driver of service innovation: An analysis of innovative KIBS business in Finland and the UK. International Journal of Service Technology and Management, 9(3/4), 268-284. https://doi.org/10.1504/IJSTM.2008.019707

Päällysaho, S., \& Kuusisto, J. (2011). Informal ways to protect intellectual property (IP) in KIBS business. Innovation: Management, Policy \& Practice, 13(1), 62-76. https://doi.org/10.5172/impp.2011.13.1.62

Papke-Shields, K. E., Malhotra, M. J., \& Grover, V. (2002). Strategic manufacturing planning systems and their linkage to planning system success. Decision Science, 13(1), 1-30. https://doi.org/10.1111/j.1540-5915.2002.tb01634.x

Rogers, M. (2004). Networks, firm size and innovation. Small Business Economics, 22(2), 141-153. https://doi.org/10.1023/B:SBEJ.0000014451.99047.69

Satorra, A., \& Bentler, P. M. (1988). Scaling corrections for chi square statistics in covariance structure analysis. American Statistics Association 1988 Proceedings of the Business and Economic Sections, 208-313.

Schumpeter, J. A. (1934). The theory of economic development: An inquiry into profit, capital, credit, interest and the business cycle. Cambridge, MA: Harvard University Press.

Segars, A. H., \& Grover, V. (1993). Re-examining perceived ease of use and usefulness: A confirmatory factor analysis. MIS Quarterly, 17(4), 517-525. https://doi.org/10.2307/249590

Steinberger, B. S. (1990). US intellectual property protection for business. Unpublished manuscript.

Tang, P., \& Molas-Gallart, J. (2004). Securing intellectual property in collaborative environments: A guide. Brighton: SPRU, University of Sussex.

US Department of Commerce. (1992). Basic facts about trademarks. Washington, DC: Patent and Trademark Office.

WIPO. (2003). WIPO survey of intellectual property services of European technology incubators. Mimeo, Geneva: WIPO.

\section{Copyrights}

Copyright for this article is retained by the author(s), with first publication rights granted to the journal.

This is an open-access article distributed under the terms and conditions of the Creative Commons Attribution license (http://creativecommons.org/licenses/by/4.0/). 